SKETCH OF THE SCENE OF THE CEREMONY

$S \underset{E}{\stackrel{+}{t}} \mathrm{~N}$

DALEM PRABASUJASA

PARINGGITAN

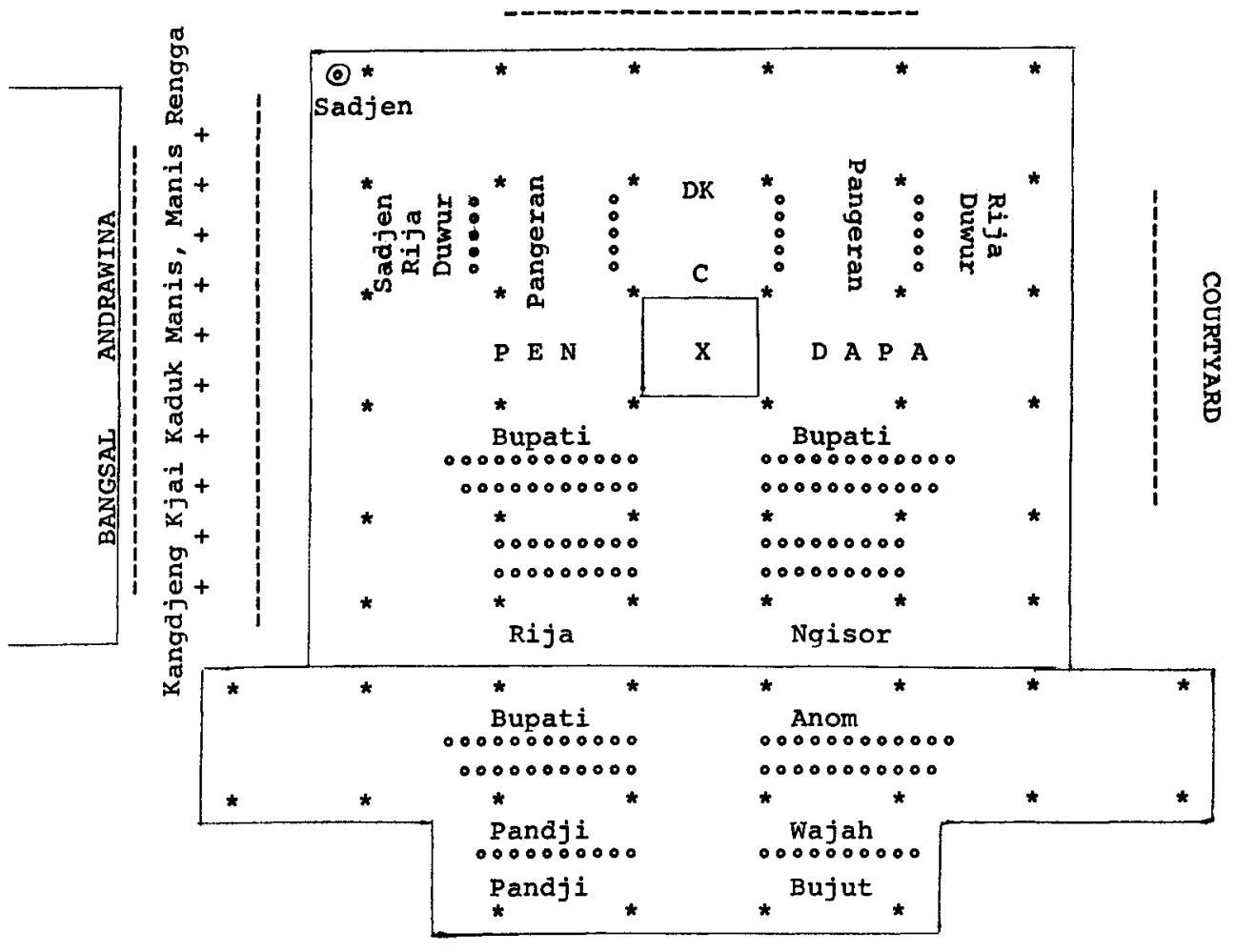

$\underline{\text { Key }}$

* Pillars of the Pendapa Sasanasewaka

---- Steps

0000 Courtiers

DK Dampar Kentjana, seat of the Susuhunan

C Red Carpet $x$ Chandelier marking the center of the Pendapa proper

$+\quad$ Nijaga

Area in which the Bedaja Ketawang is actually danced

() Sadjen and incense-brazier 


\title{
DIACHRONIC FIELD-NOTES ON THE CORONATION ANNIVERSARY AT THE KRATON SURAKARTA \\ HELD ON DECEMBER 18, 1963*
}

\author{
Benedict R. O'G. Anderson
}

\section{$8: 45$ approx.}

The gamelan Nguju-uju (without rebab or pasinden, i.e., bonagan), begins to play. It is placed on the outer, northeastern rim of the inner courtyard, opposite the Pendiapa Sasanaséwaka, immediately in front of the Art Gallery.

$9: 45$

Female attendants begin to assemble informally on the south side of the paringgitan--the ground-level space between the raised Pendiapa and the steps leading up into the Dalem Prabasujasa (see diagram). The north side of the paringgitan is still empty. In the covered gallery on the northern rim of the inner courtyard, the royal princes are seated, awaiting the summons of the Susuhunan.

$9: 55$

The Nguju-uju comes to an end. There are now about 50 or 60 women, some with their daughters, gathered on the south side of the paringgitan.

$10: 00$

Figures begin to appear from the shadowy interior of the Dalem. First come female attendants carrying the sacred royal attributes. There appear to be about ten in all: 2 long tombak (spears or lances), 2 shorter tombak, 2 swords, 2 fan-like clusters of peacock-feathers, 1 shield or targe and 1 short staff (tongkat?). They appear in single file, moving down the steps of the Dalem along the southern edge of the paringgitan, till they reach the rim of the Pendapa. The attendants with the shorter and smaller attributes stand closest to the Pendapa, while those with the long tombak are just by the open doors of the Dalem. They now stand in a single line facing north.

* The making of these crude field-notes was only made possible by the gracious permission granted by H.R.H. Sri Susuhunan Pakubuwana XII to the author to attend this ceremony. The author wishes to express his deep gratitude for this privilege. He also would like to thank G.P.H. Soerjobroto for his indispensable help and ever-ready information about the ceremonies described. Mr. N. Tirtaamidjaja also has the author deep in his debt for introducing and guiding him into the world of classical Javanese music and dance. 
With the attributes now in place, the sacred musical instruments are brought out of the Dalem, preceded by a female attendant carrying a brazier of glowing charcoal. The instruments consist of two rebab, wrapped in tjindé cloth, and a kendang covered with a plain red cloth. The rebab are identified as Kangdjeng Kjai Grantang and Kangdjeng Kjai Udan

Padjaten, but the name of the kendang I have not managed to learn. The instruments are placed, with their covers, immediately in front of the gamelan to be used for the Ketawang performance, Kangdjeng Kjai Kaduk Manis/Manis Rengga. The regular gong(s?) of this ensemble has (have?) been replaced for this occasion by the sacred gong(s?) Kangdjeng Kjai Kumitir. There are now about 80 women seated on the southside of the paringgitan, and 3 or 4 on the steps leading up to the Pendapa.

\section{0:10 approx.}

The nijaga (gamelan players) move across the courtyard to the south side of the Pendapa, and take up their places at the gamelan Kangdjeng Kjai Kaduk Manis/Manis Rengga.

$\underline{10: 13}$

The Ratu Alit, the eldest daughter of the late Susuhunan Pakubuwana $X$, grandfather of the present Susuhunan, accompanied by a pangeran, walks slowly across the courtyard from the northern entrance, enters the paringgitan, and disappears into the Dalem.

$10: 16$

The klenéngan begins, in pëlog. There are 10 nijaga playing, led by $\mathrm{R}$. Ng. Warsodiningrat on the small rectangular kețipung (drum). Instruments played include: slențem, demung, saron, bonang (?), rebab, gender, kenong, kempul, gong and kendang. There appear to be nine singers, 2 taledek and 7 majäng talèdèk, all of course women. Only one actually sings at any given time. The music is in the typical elegant, austere kraton Surakarta style.

$10: 23$

Women are still coming across the courtyard, circling round behind the Andrawina dining-hall, to the southern edge of the paringgitan.

$10: 26$

What are evidently important female relatives of the Susuhunan cross the courtyard from the south, and climb up into the Dalem between the clustering attendants and the row of attributebearers. They vanish inside; at the same time a small group of little boys appears on the steps of the Dalem, probably children of the royal household. They sit to the south of the attributebearers. 
$10: 36$

The closing patet of the klenëngan composition begins. There are now women sitting on the southern end of the steps from the paringgitan to the Pendapa.

$10: 40$ minutes.

The patet ends. There is now complete silence for 12

$10: 52$

The Susuhunan himself now begins to emerge from the Dalem, to the gending Srikaton. He is beautifully, but simply dressed in a dark-colored, high-collared jacket, kain and the black gold-streaked velvet 'fez' known as the kuluk. His hands are covered with rings. His entrance is highly impressive. He is followed by female attendants, bringing his official spittoon and cigarettes on red velvet cushions, and the attribute-bearers. They follow him through the paringgitan and up into the Pendapa, except for the bearers of the tombak who remain in the paringgitan.

The Princes waiting on the North side of the inner courtyard begin to move across to the Pendapa.

$10: 53$

The Susuhunan takes his seat on the damper kentjana, which looks like a large square 'stool' covered with red velvet. There appear now to be 6 people singing the gending Srikaton, three women and three men, one of them the saron-player who has abandoned his instrument. The nijaga are dressed in beskap, kain and blangkon, the women in kain and kemben.

\section{$\underline{10: 55}$}

The senior pangeran come into the Pendapa and take their seats, ten in all. They sit in two rows, at right-angles to the Susuhunan, five on each side.

\section{$\underline{10: 58}$}

The Njai Toemenggoeng enters the Pendapa from the northern entrance to the courtyard, followed by a female attendant, who is actually one of the pasindèn bedaja, the specialists in the difficult bedaja singing style. Both advance towards the susuhunan very slowly, crouching on their heels. Under the central chandelier by the Sakaguru, she turns and makes her sembah to the Susuhunan.

$\underline{10: 59}$

The gending comes to an end. The central chandelier lights up, its nocturnal glow contrasting oddly with the sunlight playing over the courtyard. 
The Njai Toemenggoeng addresses the Susuhunan in solemn, half-chanted tones. She receives instructions from the Susuhunan, and acknowledges them with three sembah.

$11: 01$

The klenëngan begins again. Pélog. There are again 3 male and 3 female singers. The Njai Toemenggoeng and her attendant turn and crawl slowly to the northern edge of the Pendapa.

11:02

At the edge of the Pendapa the two women rise to their feet and cross the countyard, vanishing through the northern entrance. It appears that she is giving orders to the palace officials organizing a slametan outside, and instructing the nijaga at the ancient gamelan Munggang to start playing.

$11: 05$

One can hear the repetitive, hypnotic three-note motif of the Gamelan Munggang from outside the main courtyard.

11:09

The Njai Toemenggoeng reappears in the distance with her attendant.

$11: 10$

They reach the edge of the Pendapa.

$11: 11$

The Njai Toemenggoen crawls on her heels to the center of the Pendapa, makes her sembah, and then waits, utterly still, for the end of the gending.

\section{$11: 13$}

The gending ends. The $\mathrm{Njai}$ Toemenggoeng makes her sembah again and reports to the susuhunan in the same half-chanted tones. She then receives further orders from the susuhunan. The Pendapa is still largely empty.

$\underline{11: 15}$

The Njai Toemenggoeng acknowledges the orders with a threefold sembah, and crawls with her attendant to the edge of the Pendapa.

$11: 16$

The Njai Toemenggoeng sits on the north edge of the Pendapa. She appears to give instructions to her attendant. Two 
other pasinden bedaja appear, one of them an immensely large and robust-looking woman, and are sent to summon the lower court officials.

\section{$11: 20$}

A new gending begins--klenéngan. Is it Gambir Sawit? The two pasinden reappear from the outer courtyard, where they have summoned the lower court officials, who follow behind them. They all move in a slow circle to the eastern side of the Pendapa, opposite the susuhunan and enter in two lines, two by two. Each makes his sembah as he enters the Pendapa, appears to get a signal of approval to advance, makes a further sembah and takes his seat. The older courtiers precede the younger.

$\underline{11: 24}$

All are seated.

$11: 25$

As the gending ends, the pasindèn bedaja return to their proper places in front of the gamelan Kangdjeng Kjai Kaduk Manis/Manis Rengga.

$11: 26$

The four pasindèn bedaja are now seated in their places.

11:27

Four court officials now rise and present themselves before the Susuhunan, making their sembah. All come from the Susuhunan's right (the South), one from the front row of princes (G.P.H.?), three from the second row, behind (B.P.H.? Rija Duwur?). They appear to be the courtiers in charge of the protocol for the following "promotion" ceremonies.

$11: 29$

The four officials make a further sembah, and summon an official (Bupati?) from the front row of courtiers sitting facing the susuhunan, who in turn summons a courtier from among the officials sitting further away, outside the Pendapa proper. (Is he a Bupati Anom?).

$11: 30$

All six now stand facing the Susuhunan, and make their sembah. The elderly prince acts as intermediary between the Susuhunan and the new appointees, whose promotions are now made.

$11: 31$

The prince stays where he is, in front of the Susuhunan, while his three aides escort the first appointee to a seat 
appropriate to his new rank, in the back row of the group of officials sitting on the Susuhunan's left (north).

\section{$11: 32$}

The three aides return and escort the second appointee to his new seat with them, in the back row of officials sitting to the Susuhunan's right (south).

$11: 33$

The same procedure occurs with another aged official (Bupati?) who is given a place among the Rija Duwur to the Susuhunan's left.

$11: 35$

An extremely ancient official (Bupati?), who has to be supported as he walks, is brought before the Susuhunan. He makes his sembah, is told of his promotion by the elderly prince, appears to express his gratitude through the same channel, and is helped to his place among the Rija Duwur to the Susuhunan's right.

$11: 36$

In a 1-1-2 formation the four protocol officers now face the susuhunan, while the elderly prince reports on their behalf.

$11: 38$

They return to their places. The Njai Toemenggoeng now re-enters the Pendapa on her heels, followed by her attendant. Incense is burning heavily in the brazier, which has been placed to the left (west) of the gamelan ensemble.

11:39

The Njai Toemenggoeng reports as before, and receives orders to command the music for the Bedaja Ketawang to begin. She makes the three-fold sembah, and crawls slowly over to the nijaga. Her attendant follows her, but then passes behind her down the steps of the Pendiapa to take her place among the other pasindien. The $\mathrm{Njai}$ Toemenggoeng gives the impression of being angry about something, making faces at the nijaga. One can see her quite clearly as she is only a few yards away. She then turns and sits down on the southern rim of the Pendapa, facing north.

$11: 41$

Two aged courtiers bring tea and cigarettes for the Susuhunan. They are followed by a group of djongos, dressed like waiters in western style, who are carrying trays with tea and cigarettes for the court officials. The djongos do not crawl 
or sembah, but stand or walk about quite nonchalantly, giving an odd impression of insolence.

$\underline{11: 42}$

The courtiers, observing that the Susuhunan has begun drinking his tea, feel they can follow suit.

$\underline{11: 43}$

The djongos now leave down the center of the Pendapa, eastwards, away from the Susuhunan, turning their backs to him and making no visible sign of homage.

$11: 44$

The Njai Toemenggoeng commands the singers to begin the Suluk which precedes the opening of the Bedaja Ketawang. The suluk is sung by four male singers, accompanied by rebab and gendèr.

$\underline{11: 46}$

There are now 5 pasindèn bedaja, two of the younger singers joining the three 'experts.' The Njai Toemenggoeng's attendant will open the second, most evocative portion of the performance (the section beginning "Semang, semang").

$11: 49$

The dancers can be seen emerging from the shadowy Dalem. Preceded by the celebrated bedaja teacher, Njai Lurah Bedaja, who advances crouching on her heels, they descend into the paringgitan. They are followed by two younger attendants, also crouching, who are there to arrange the trains of their ceremonial array.

11:51

The dancers go up into the Pengapa in single file, passing the Susuhunan on his left hand side.

$11: 52$

The file now changes direction, from east to south. The leading dancer, the Endel, has Njai Lurah Bedaja crouching to her left.

11:54

The dancers now face west, in a long line opposite the susuhunan. They slowly sit down and make their sembah.

$\underline{11: 55}$

The pațetan--suluk ends. 
Now the Bedaja Ketawang proper begins. The only instruments playing are the rhythmic and colotomic guides: kendang ageng, ketipung, kemanak, ketuk, kenong and gong. (Is thére possibly also a kempjang?) The intensely impressive effect of the music comes from the harsh and poignant choral singing of the pasingèn.

\section{$12: 11$}

The first section of the Ketawang ends after 16 minutes. The more mysterious second section begins. During this portion of the dance, the sunny courtyard outside the Pendapa darkens-the sun seems to be overclouded. Inside the Pendapa one gets a little the sense that night is falling. But throughout, the senior pangeran chat and gossip quietly, appearing to be unaffected by the distinct change in atmosphere.

$\underline{12: 50}$

After 39 minutes the second part of the dance ends. The last section now begins.

$1: 17$

The last section is over, lasting 27 minutes in all. The patetan--Suluk is now played. The dancers sembah, then rise rather informally, the Susuhunan's wives (five of the nine dancers) taking the lead. Maintaining a single file, they turn south and then west between the front and back rows of courtiers to the Susuhunan's right. They continue slowly down into the paringgitan, and up towards the Dalem, vanishing into the darkness from which they came.

$1: 24$

The dancers have disappeared. The djongos now reappear to serve tea to the Susuhunan and the assembled court.

$\underline{1: 25}$

The 8-minute patetan ends. The whole Bedaja Ketawang, including the patetan has lasted 101 minutes. The nijaga change places. The instruments now played include the normal instruments for bonangan-style compositions (i.e., without the rebab), but also the gambang gangsa, a rarely used metal gambang.

$1: 27$

The Susuhunan stands up, and moves back towards the Dalem followed by the bearers of the royal attributes. The Dampar Kentjana is carried in after him. The courtiers begin to move out of the Pendapa with surprising rapidity. The gending played to usher the Susuhunan out is the traditional Oendoer-oendoer Kadjongan or Tjalapita. 
$1: 29$

The last of the attribute-bearers disappears. The women in the paringgitan begin to melt away, the djongos remove the glasses and spittoons. The senior pasindèn bedaja start wrapping up the holy rebab and kendang in their respective cloths.

$1: 30$

The gending Oendoer-oendoer kadjongan ends.

$1: 31$

The nijaga begin to leave. The big red-clothed kendang is lugged off into the Dalem. The sadjen are prepared for removal.

$1: 33$

The rebab are carried off into the Dalem.

$1: 35$

The sadjèn are taken out by the southern entrance, to be placed later in a place sacred to the Goddess of the Southern Sea, Njai Loro Kidul.

The ceremony is over, the Pendapa empty except for the rows of empty chairs. The chandeliers have gone out. Almost before one knows it the entire inner courtyand is empty, the courtiers slipping out silently and rapidly. But the sun has come out again. 
